Archive for

Organic Chemistry

Arkivoc 2019, part vi, 239-251

\title{
A new and efficient synthesis of unsaturated benzoxazepines using sodium metabisulfite and potassium permanganate as oxidative reagents
}

\author{
Muhammad Ashram*a and Firas F. Awwadi ${ }^{b}$ \\ ${ }^{a}$ Chemistry Department, Mutah University, Al-Karak, Jordan \\ ${ }^{b}$ Chemistry Department, The University of Jordan, Amman, Jordan, 11942 \\ E-mail: ashram1961@yahoo.com
}

Received 09-09-2019

Accepted 10-24-2019

Published on line 12-04-2019

\section{Abstract}

A mild oxidation of $1,2,3,5,6,11$ b-hexahydroimidazo[1,2-d][1,4] benzoxazepines using $\mathrm{KMnO}_{4}$ in $\mathrm{DMF}$ at room temperature produces a mixture of unsaturated and partially unsaturated [1,4]benzoxazepines in very good yields. Condensation of 2-(2-bromoethoxy)benzaldehydes with either o-phenylenediamine or ethylenediamine in the presence of oxidative reagents such as sodium metabisulfite in acetonitrile at reflux temperature produces a series of [1,4]benzoxazepines, in a simple way and in good yields. Structures of all the synthesized compounds were established in detail via NMR, HRMS spectra and single-crystal X-ray diffraction analyses.<smiles>[Y]c1cc2c(cc1[Y])C(=NCCC(C)C)c1cc([Y])c([X])cc1C1=NCCN1CCO2</smiles>

Keywords: Sodium metabisulfite, potassium permanganate, 2-(2- bromoethoxy)benzaldehydes, ethylenediamine, unsaturated $[1,4]$ benzoxazepines 


\section{Introduction}

1,4-Benzoxazepines are of pharmacological interest due to their activity on the central nervous system, as enzyme inhibitors, or as analgesics and antitussives. ${ }^{1}$ The 1,4-oxazepine structure is the parent core of medicinal drugs like amoxapine, loxapine and sintamil. ${ }^{2,4}$ It was reported that 1,4-oxazepine derivatives exhibit biological activity as histone deacetylase inhibitors and as antitumor agents. ${ }^{5,6}$ The privileged 5,6dihydroimidazobenzoxazepines and 6,7-dihydrobenzo[f]benzoimidazoloxazepines and similar structures are found in numerous medicinally relevant compounds. ${ }^{7-10}$ In recent decades, many compounds with potent activity against P13K $\alpha$ and NIK have been intensely pursued as potential treatments for various types of cancers and some of these have recently advanced into the clinic (Figure 1). ${ }^{71-14}$

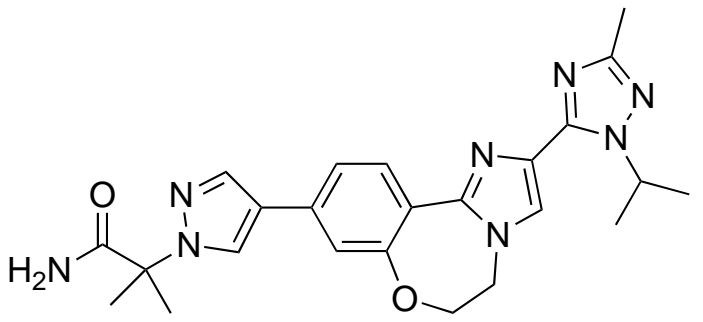

1

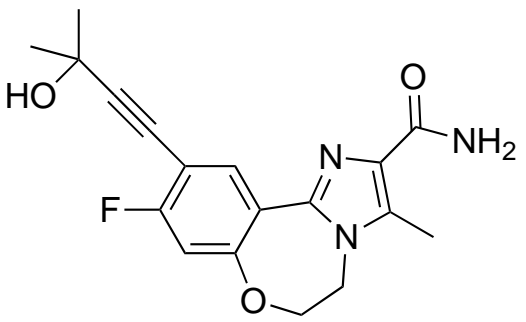

2

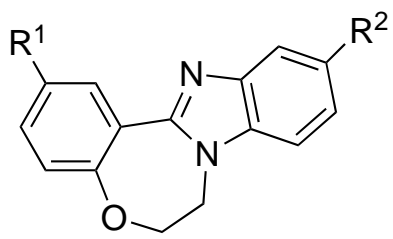

3

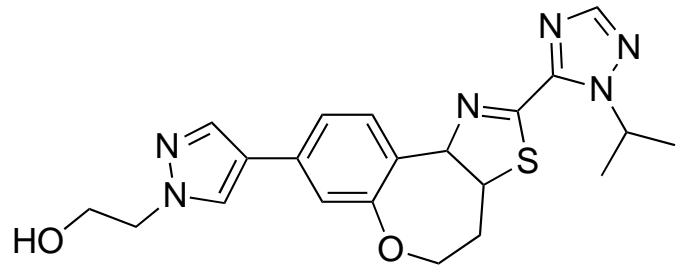

4

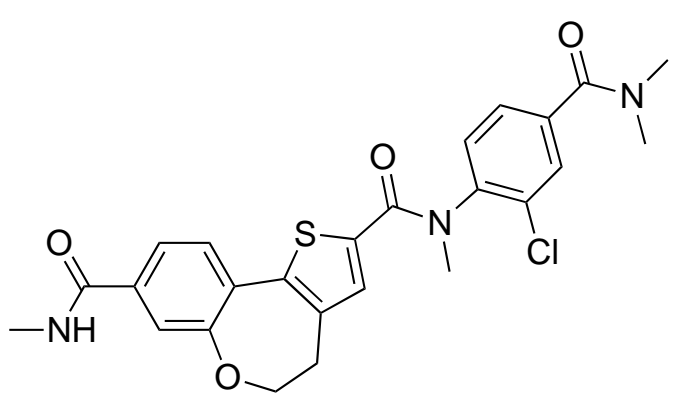

5

Figure 1. Structures of some benzoxazepines and similar structures that have potent activity against P13K $\alpha$ and NIK.

Several approaches have been used to synthesize 5,6-dihydroimidazobenzoxazepines and 6,7dihydrobenzo[f]benzoimidazoloxazepines and their derivatives. Among these approaches are: (i) treatment of benzaldehydes with glyoxal and ammonia followed by bis-alkylation with 1,2-dibromoethane; ${ }^{9}$ (ii) magnesium ethoxide-promoted conversion of nitriles into amidines and its application in 5,6dihydroimidazobenzoxazepine synthesis; ${ }^{15}$ (iii) treatement of 2-(2-formylphenoxy)acetic acid with 0 phenylenediamine using manganese(II) complex tetrasulfophthalocyanine complex supported on natural silk as catalyst; ${ }^{16}$ (iv) condensation of various ortho-phenylenediamines with 2-(prop-2-yn-1-yloxy)benzaldehydes to produce imidazole derivatives followed by intramolecular cyclization forming 7-methylene-6,7dihyrobenzo[f]benzo[4,5]imidazo[1,2-d][1,4]oxazepines; ${ }^{17}(\mathrm{v})$ condensation between 1,2-diketones, 2-formyl phenoxy acetic acids, and ammonium acetate in acetic acid under reflux conditions; ${ }^{18}$ (vi) condensation of salicylaldehyde with ortho-phenylenediamine using sodium metabisulfite as a catalyst which forms a benzimidazole phenol followed reaction with 1,2-dibromoethane in the presence of base; ${ }^{10}$ (vii) a one-pot combination of condensation, Mannich, oxidation, and aza-Michael addition reactions, employing a variety of 
functionalized anilines and aldehydes suitably poised with a Michael acceptor. Scandium triflate $\left(\mathrm{Sc}(\mathrm{OTf})_{3}\right)$ in acetonitrile was found to promote the construction of benzoxazepines scaffolds. ${ }^{19}$

Levan et al. reported the isolation and characterization of the unsubstituted 1,2,3,4,5,6,11-hexahydro imidazo-[1,2- $d$ ] benzoxazepine as a by-product in a tedious route and without mentioning the product yield. $^{20,21}$

\section{Results and Discussion}

Recently, we reported new and a convenient synthetic methods for synthesis of [1,4]benzoxazepines. ${ }^{22,23}$ In continuation of our research program regarding the synthesis of biologically active nitrogen heterocycles, herein we describe development of new and straightforward approaches for preparation of 5,6dihydroimidazobenzoxazepines 20-26 and 6,7-dihydrobenzo[f]benzimidazoloxazepines 35-39, in good yields (Figure 2).

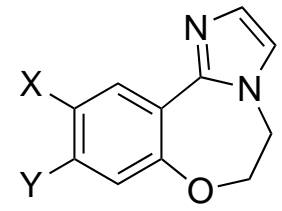

$20 \mathrm{X}=\mathrm{Y}=\mathrm{H}$

$21 \mathrm{X}=\mathrm{Cl}, \mathrm{Y}=\mathrm{H}$

$22 \mathrm{X}=\mathrm{Br}, \mathrm{Y}=\mathrm{H}$

$23 \mathrm{X}=\mathrm{CH}_{3}, \mathrm{Y}=\mathrm{H}$

$24 \mathrm{X}=\mathrm{OCH}_{3}, \mathrm{Y}=\mathrm{H}$

$25 \mathrm{X}=\mathrm{NO}_{2}, \mathrm{Y}=\mathrm{H}$

$26 \mathrm{X}+\mathrm{Y}=\mathrm{HC}=\mathrm{CH}-\mathrm{CH}=\mathrm{CH}$

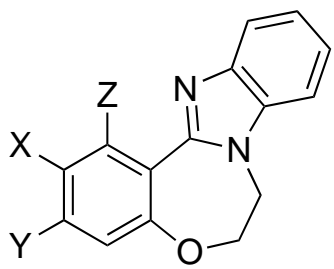

$35 \mathrm{X}=\mathrm{Y}=\mathrm{Z}=\mathrm{H}$

$36 \mathrm{X}=\mathrm{Br}, \mathrm{Y}=\mathrm{Z}=\mathrm{H}$

$37 X=\mathrm{NO}_{2}, \mathrm{Y}=\mathrm{Z}=\mathrm{H}$

$38 \mathrm{X}+\mathrm{Y}=\mathrm{HC}=\mathrm{CH}-\mathrm{CH}=\mathrm{CH}, \mathrm{Z}=\mathrm{H}$

$39 \mathrm{X}+\mathrm{Z}=\mathrm{HC}=\mathrm{CH}-\mathrm{CH}=\mathrm{CH}, \mathrm{Y}=\mathrm{H}$

Figure 2. Structures of 5,6-dihydroimidazobenzoxazepines 20-26 and 6,7-

dihydrobenzo[f]benzimidazoloxazepines 35-39.

The synthetic pathway for preparation of targeted compounds 20-26, is shown in Scheme 1. It starts from the condensation of 2-(2-bromoethoxy)benzaldehydes 6-12 with ethylene diamine in the presence of anhydrous $\mathrm{K}_{2} \mathrm{CO}_{3}$ and acetonitrile at reflux temperature to give the corresponding saturated oxazepines 1319. ${ }^{22,23}$ In addition to its ${ }^{1} \mathrm{H},{ }^{13} \mathrm{C}$ NMR and mass spectra, the structure of compound $\mathbf{1 6}$ was confirmed by $\mathrm{X}$-ray analysis as shown in Figure 3. Oxidation of 13-19 with potassium permanganate in DMF at room temperature produced the targeted unsaturated benzoxazepines 20-26 in addition to the partially unsaturated benzoxazepines 27-33 in very good yields. Several experimental trials were carried out such as increasing the equivalents of $\mathrm{KMnO}_{4}$ and/or increasing the reaction temperature to $65{ }^{\circ} \mathrm{C}$ in attempts to produce only unsaturated oxazepines 20-26, failed. The unsaturated oxazepine $\mathbf{4 0}$ (where $X=Y=H$ ) was not detected in the crude products. 


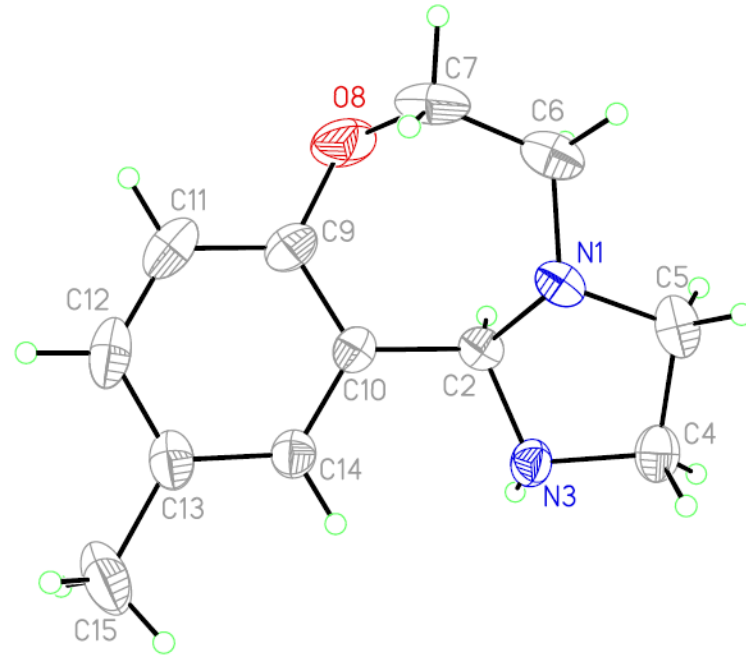

Figure 3. Crystal structure of oxazepine 16. Thermal ellipsoids are shown at $30 \%$ probability.<smiles>[Y]c1cc(C=O)c(OCCBr)cc1[Y]</smiles>

$6 \mathrm{X}=\mathrm{Y}=\mathrm{H}$

$7 \mathrm{X}=\mathrm{Cl}, \mathrm{Y}=\mathrm{H}$

$8 \mathrm{X}=\mathrm{Br}, \mathrm{Y}=\mathrm{H}$

$9 \mathrm{X}=\mathrm{CH}_{3}, \mathrm{Y}=\mathrm{H}$

$10 \mathrm{X}=\mathrm{OCH}_{3}, \mathrm{Y}=\mathrm{H}$

$11 \mathrm{X}=\mathrm{NO}_{2}, \mathrm{Y}=\mathrm{H}$

$12 \mathrm{X}+\mathrm{Y}=\mathrm{CH}=\mathrm{CH}-\mathrm{CH}=\mathrm{CH}$<smiles>[Y]c1cc2c(cc1[X])-c1nccn1C=CO2</smiles><smiles>[Y]c1cc2c(cc1[X])-c1cc([X])c([X])cc1C1NCCN1CCO2</smiles>

$13 \mathrm{X}=\mathrm{Y}=\mathrm{H}$

$14 \mathrm{X}=\mathrm{Cl}, \mathrm{Y}=\mathrm{H}$

$15 \mathrm{X}=\mathrm{Br}, \mathrm{Y}=\mathrm{H}$

$16 \mathrm{X}=\mathrm{CH}_{3}, \mathrm{Y}=\mathrm{H}$

$17 \mathrm{X}=\mathrm{OCH}_{3}, \mathrm{Y}=\mathrm{H}$

$18 \mathrm{X}=\mathrm{NO}_{2}, \mathrm{Y}=\mathrm{H}$

$19 \mathrm{X}+\mathrm{Y}=\mathrm{CH}=\mathrm{CH}-\mathrm{CH}=\mathrm{CH}$
$20 \mathrm{X}=\mathrm{Y}=\mathrm{H}$

$21 \mathrm{X}=\mathrm{Cl}, \mathrm{Y}=\mathrm{H}$

$22 \mathrm{X}=\mathrm{Br}, \mathrm{Y}=\mathrm{H}$

$23 \mathrm{X}=\mathrm{CH}_{3}, \mathrm{Y}=\mathrm{H}$

$24 \mathrm{X}=\mathrm{OCH}_{3}, \mathrm{Y}=\mathrm{H}$

$25 \mathrm{X}=\mathrm{NO}_{2}, \mathrm{Y}=\mathrm{H}$

$26 \mathrm{X}+\mathrm{Y}=\mathrm{CH}=\mathrm{CH}-\mathrm{CH}=\mathrm{CH} 33 \mathrm{X}+\mathrm{Y}=\mathrm{CH}=\mathrm{CH}-\mathrm{CH}=\mathrm{CH}$

Scheme 1. Preparation of compounds 20-26 and 27-33.

The compounds 20-26 and 27-33 were characterized by ${ }^{1} \mathrm{H},{ }^{13} \mathrm{C} N M R$ and high resolution mass spectroscopy. The mass spectra of prepared compounds displayed the correct molecular ion peaks for which the measured high resolution (HRMS) data were in good agreement with the calculated values. Spectral data, detailed in the experimental part, are consistent with the suggested structures. The structures of compounds 27-33 were confirmed by disappearance of CHNN and the secondary amine proton signals that usually show up as a sharp singlet and broad signals at around $\delta=5$ and $2.4 \mathrm{ppm}$, respectively, in their corresponding saturated oxazepines 13-19. Additionally, structure of compound 29 was confirmed by X-ray analysis as shown in Figure 4. 
In a similar manner, several experimental trials were carried out to condense 2-(2bromoethoxy)benzaldehyde 6 with ortho-phenylenediamine as an example, failed and only a complex inseparable mixture of products was formed. Usually, one of the methods that is used in preparation of 2arylbenzimidazoles is the condensation of ortho-phenylenediamines with aldehydes in the presence of oxidative reagents such as sodium metabisulfite. ${ }^{24}$ Accordingly, when $\mathrm{K}_{2} \mathrm{CO}_{3}$ was replaced with sodium metabisulfite, compound $\mathbf{3 5}$ was formed straightforwardly and as a unique product in a one-pot process. We believe that the condensation of phenylenediamine with aldehyde 6 under oxidative condition generates first the benzimidazole core followed by intramolecular nucleophilic substitution between nitrogen of the benzimidazole ring and 2-(2-bromoethoxy) unit. Using this strategy, a series of 6,7-dihydrobenzo[f]-4,5imidazo[1,2-d][1,4] oxazepines 35-39 were prepared in easily and in good yields (Scheme 2). ${ }^{1} \mathrm{H}$ NMR spectra of compounds 35-39 in $\mathrm{CDCl}_{3}$ show two multiplets centered at about 4.5 and $4.6 \mathrm{ppm}$ corresponding to the two methylene protons of the benzoxazepine ring. Their ${ }^{13} \mathrm{C} \mathrm{NMR}$ spectra in $\mathrm{CDCl}_{3}$, displayed two signals at about 47 and $69 \mathrm{ppm}$ which also corresponding to the carbon atoms of the oxazepine ring. Additionally, the structure of compound $\mathbf{3 6}$ was confirmed by X-ray analysis as shown in Figure 5 . Inspired by these results, we turned our attention again to the condensation of aldehydes $\mathbf{6}$ and $\mathbf{8}$, as examples, with ethylenediamine in the presence of sodium metabisulfite. Indeed, when aldehydes $\mathbf{6}$ or $\mathbf{8}$ were condensed with ethylenediamine in the presence of sodium metabisulfite in acetonitrile at reflux temperature, products whose physical and spectroscopic properties (mp, NMR and HRMS) were identical to those of $\mathbf{2 7}$ and $\mathbf{2 9}$, in yields of $52 \%$ and $49 \%$ respectively, were obtained.

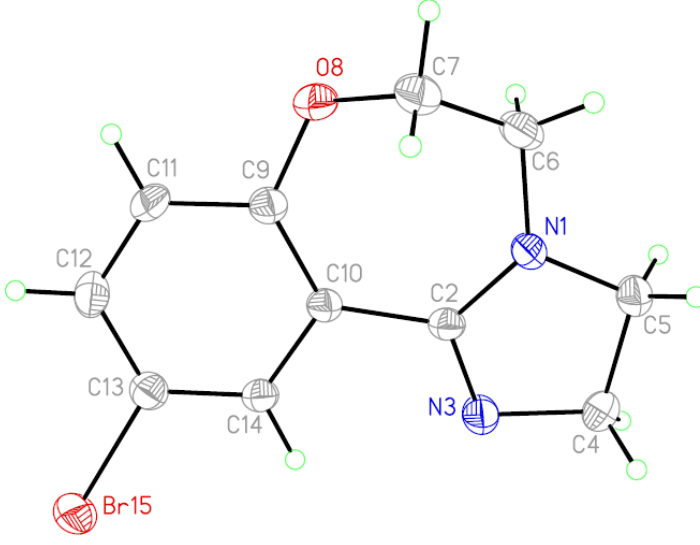

Figure 4. Crystal structure of oxazepine 29. Thermal ellipsoids are shown at 30\% probability.

The seven-memebered ring is nonplanar in the three compounds (16, 29 and 36). The mean deviations of the atoms (N1, C2, C6, C7, O8, C9 and C10) from the average plane are $0.2654 \AA$, $0.1470 \AA 0.1757 \AA$, for 16, 29 and 36, respectively. The degree of non-planarity is the highest in $\mathbf{1 6}$ and due to that, the five-membered ring is nonplanar, whereas it is planar in $\mathbf{2 9}$ and $\mathbf{3 6}$. The average deviation of the atoms N1, C2, N3, C4 and C5 are $0.1584 \AA, 0.0029 \AA$ and $0.0386 \AA$ for 16, 29 and 36, respectively. This is due to the fact that $C 2$ is $s p^{2}$ hybridized in $\mathbf{2 9}$ and $\mathbf{3 6}$ while it is sp ${ }^{3}$ hybridized in 16. The C2-N3 is single bond in 16 (bond distance = 1.456(3) and double bond in 29 and 36 (bond distance $=1.281(5) \AA$ ). 


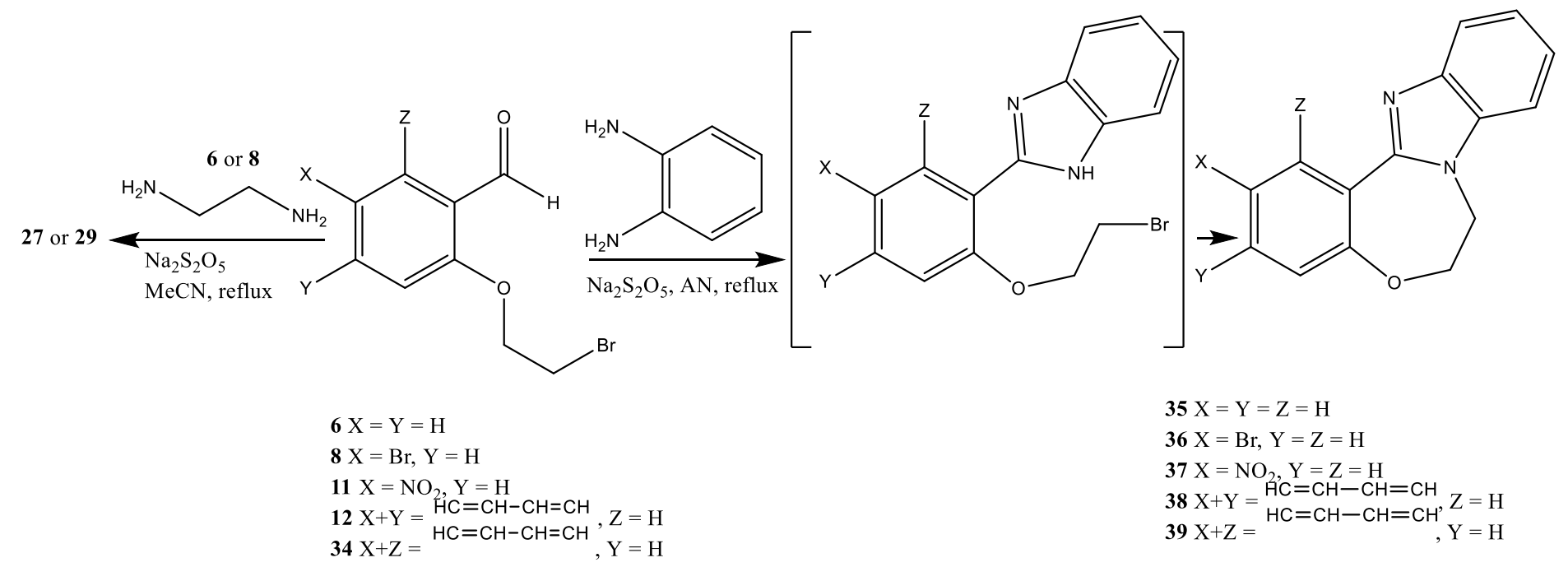

Scheme 2. Preparation of compounds 35-39.

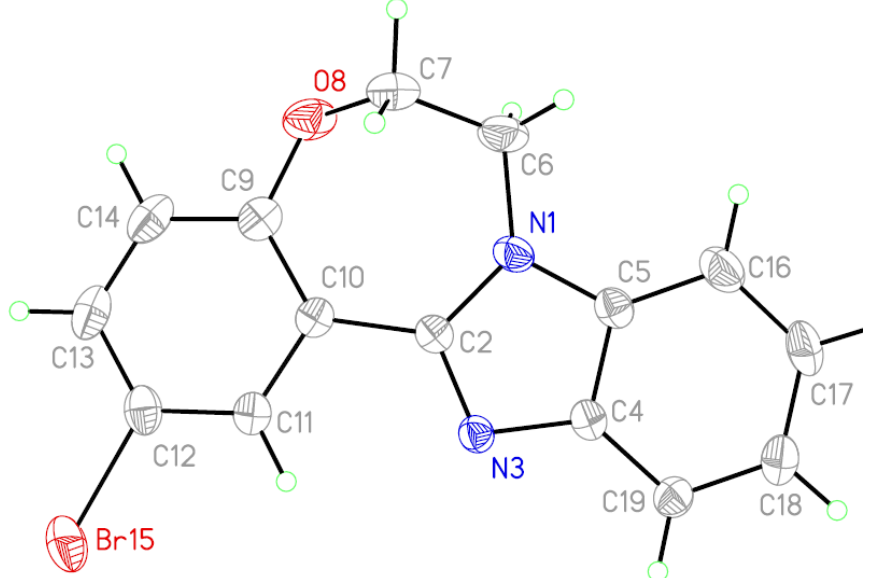

Figure 5. Crystal structure of oxazepine 36. Thermal ellipsoids are shown at $30 \%$ probability.

The supramolecular structure of the three compounds $(16,29$ and 36) is developed based on $\mathrm{N}-\mathrm{H}$... N hydrogen bonding interactions and $\mathrm{C}-\mathrm{Br}$... N halogen bonding interactions in addition to other weaker interactions based on $\mathrm{C}-\mathrm{H}$ groups. The interactions based on $\mathrm{C}-\mathrm{H}$ groups are not analyzed due to the abundance of these groups. The crystal structure of $\mathbf{1 6}$ is developed based on $\mathrm{N}-\mathrm{H}$...N hydrogen bonding interactions. Hydrogen bond parameters are $2.266 \AA, 3.153 \AA$ and $168.9^{\circ}$ for $H \ldots N, N . . N$ and $N-H . . . N$, respectively. Hydrogen bonding interactions link the molecular units to chain structures running parallel to crystallographic C-axis (Figure 6A). Due to the absence of strong proton donor ( $\mathrm{N}-\mathrm{H}$ group) in 29 and $\mathbf{3 6}$ and the presence of a halogen donor ( $\mathrm{C}-\mathrm{Br}$ group), halogen bonding interactions connect the molecular units to form a dimer structure as shown in Figures $6 \mathrm{~B}$ and 6C. The $\mathrm{Br} . . \mathrm{N}$ distances are $3.374 \AA$ and $3.392 \AA$ for 29 and

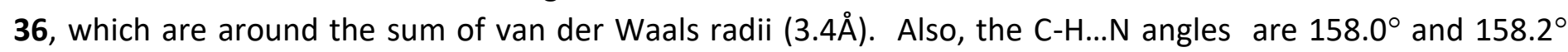
which are in suitable arrangement for halogen bonding interactions. ${ }^{25}$ 

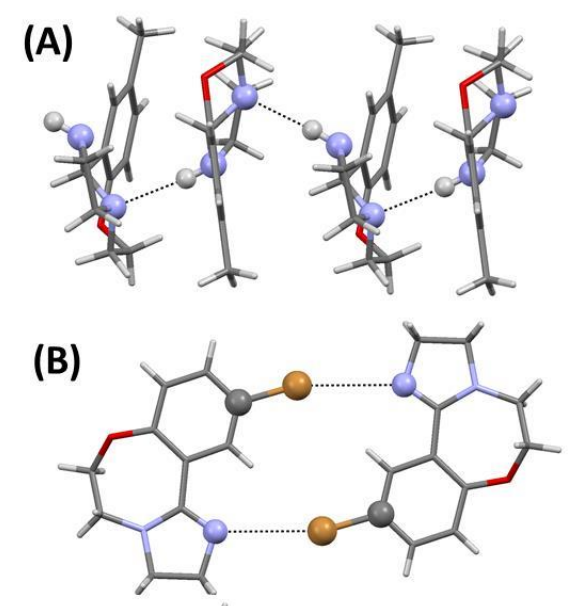

(C)

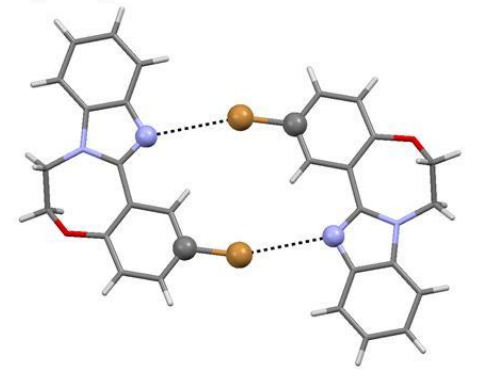

Figure 6. Illustration of hydrogen bonding interaction in $16(A)$, halogen bonding interactions in 29 (B) and 36 (C).

\section{Conclusions}

Oxidation of $1,2,3,5,6,11 b$-hexahydroimidazo[1,2- $d][1,4]$ benzoxazepines with potassium permanganate in DMF at room temperature produced a mixture of unsaturated and partially unsaturated oxazepines in very good yields. Condensation of 2-(2-bromoethoxy)benzaldehydes with 0 -phenylenediamine in the presence of oxidative reagents such as sodium metabisulfite in acetonitrile at reflux temperature produced a series of 6,7dihydrobenzo[f]-4,5-imidazo[1,2- $d][1,4]$ oxazepines, in a one-pot process. The advantages of these methods are high yields, readily available starting materials, simple procedures and straightforward purification of the products.

\section{Experimental Section}

General. Silica gel 60 for column chromatography was obtained from Fluka. The progress of reactions was monitored by means of thin-layer chromatography (TLC), carried out on TLC sheets that were visualized under UV light (where appropriate). On the other hand, preparative thick layer $(0.25 \mathrm{~mm})$ chromatography was performed on silica gel glass plates (60 F-254, $20 \mathrm{~cm} \times 20 \mathrm{~cm}$, Fluka). Melting points were determined on a Stuart scientific melting point apparatus in open capillary tubes and are uncorrected. ${ }^{1} \mathrm{H} N M R$ and ${ }^{13} \mathrm{C} N M R$ spectra were recorded on a $500 \mathrm{MHz}$ spectrometer (Bruker DPX-500) with TMS as the internal standard. Chemical shifts expressed in $(\delta)$ are given in ppm, whereas $J$-values for ${ }^{1} \mathrm{H}-{ }^{1} \mathrm{H}$ coupling constants are given in Hertz. High-resolution mass spectra (HRMS) were obtained (in positive/or negative ion mode) using electron spray ion trap (ESI) technique with a Bruker APEX-4 (7 Tesla) instrument. Samples were dissolved in 
acetonitrile, diluted in spray solution (methanol/water $1: 1 \mathrm{v} / \mathrm{v}+0.1 \%$ formic acid), and infused using a syringe pump with a flow rate of $2 \mu \mathrm{L} / \mathrm{min}$. External calibration was conducted using arginine cluster in a mass range $m / z$ 175-871. 2-(2-Bromoethoxy)benzaldehydes 6-12 and benzoxazepines 13, 18, 19 were prepared according to the literature. ${ }^{22,23}$ Benzoxazepines 14-17 were prepared as 13, 18 and $19 .^{22}$ Their physical properties and spectroscopic analyses were as follows:

10-Chloro-1,2,3,5,6,11b-hexahydroimidazo[1,2-d][1,4]benzoxazepine (14). The crude product was purified by washing with EtOAc to give a colorless solid; yield $88 \% ; \mathrm{mp} 65-66{ }^{\circ} \mathrm{C} ;{ }^{1} \mathrm{H} \mathrm{NMR}\left(\mathrm{CDCl}_{3}\right) \delta 2.35(\mathrm{br}, 1 \mathrm{H}), 2.58(\mathrm{~m}$, $1 \mathrm{H}), 2.90(\mathrm{~m}, 1 \mathrm{H}), 3.16(\mathrm{~m}, 2 \mathrm{H}), 3.27(\mathrm{~m}, 1 \mathrm{H}), 3.78(\mathrm{~m}, 1 \mathrm{H}), 4.29(\mathrm{~m}, 1 \mathrm{H}), 4.46(\mathrm{~s}, 1 \mathrm{H}), 6.88(\mathrm{~d}, J 8.5 \mathrm{~Hz}, 1 \mathrm{H})$, 7.05 (d, J $8.2 \mathrm{~Hz}, 1 \mathrm{H}), 7.56(\mathrm{~s}, 1 \mathrm{H}) ;{ }^{13} \mathrm{C} \mathrm{NMR}\left(\mathrm{CDCl}_{3}\right) \delta 44.1,55.8,56.4,72.4,78.2,122.4,126.5,128.4,128.9$, 136.1, 157.1; HRMS (ESI) $\mathrm{m} / \mathrm{z}$ : calculated for $\mathrm{C}_{11} \mathrm{H}_{14} \mathrm{CIN}_{2} \mathrm{O}[\mathrm{M}+\mathrm{H}]^{+} 225.0795$, found 225.0789

10-Bromo-1,2,3,5,6,11b-hexahydroimidazo[1,2-d][1,4]benzoxazepine (15). The crude product was purified by washing with EtOAc to give pale yellow solid, yield 78\%; mp 88-90 ${ }^{\circ} \mathrm{C} ;{ }^{1} \mathrm{H} \mathrm{NMR}\left(\mathrm{CDCl}_{3}\right) \delta 2.26(\mathrm{br}, 1 \mathrm{H}), 2.63(\mathrm{~m}$, $1 \mathrm{H}), 2.96(\mathrm{~m}, 1 \mathrm{H}), 3.21(\mathrm{~m}, 3 \mathrm{H}), 3.32(\mathrm{br}, 1 \mathrm{H}), 3.84(\mathrm{~m}, 1 \mathrm{H}), 4.34(\mathrm{~m}, 1 \mathrm{H}), 4.53,(\mathrm{~s}, 1 \mathrm{H}), 6.88(\mathrm{~d}, J 8.5 \mathrm{~Hz}, 1 \mathrm{H})$, $7.30(\mathrm{~d}, J 8.2 \mathrm{~Hz}, 1 \mathrm{H}), 7.77(\mathrm{~s}, 1 \mathrm{H}) ;{ }^{13} \mathrm{C} \mathrm{NMR}\left(\mathrm{CDCl}_{3}\right) \delta 44.1,55.8,56.3,72.4,78.2,116.6,122.9,129.5,131.4$, 136.7, 157.6; HRMS (ESI) $\mathrm{m} / \mathrm{z}$ : calculated for $\mathrm{C}_{11} \mathrm{H}_{14} \mathrm{BrN}_{2} \mathrm{O}[\mathrm{M}+\mathrm{H}]^{+} 269.0289$, found 269.0284 .

10-Methyl-1,2,3,5,6,11b-hexahydroimidazo[1,2-d][1,4]benzoxazepine (16). The crude product was purified by washing with MeCN to give pale yellow solid, yield 93\%; mp 90-91 ${ }^{\circ} \mathrm{C} ;{ }^{1} \mathrm{H} \mathrm{NMR}\left(\mathrm{CDCl}_{3}\right) \delta 2.30(\mathrm{~s}, 3 \mathrm{H}), 2.41$ (s, 1H), $2.61(\mathrm{br}, 1 \mathrm{H}), 2.94(\mathrm{br}, 1 \mathrm{H}), 3.21-3.34(\mathrm{~m}, 4 \mathrm{H}), 3.82(\mathrm{br}, 1 \mathrm{H}), 4.29(\mathrm{br}, 1 \mathrm{H}), 4.47,(\mathrm{~s}, 1 \mathrm{H}), 6.90(\mathrm{~d}, J 8.0$ $\mathrm{Hz}, 1 \mathrm{H}), 6.99(\mathrm{~d}, J \mathrm{~J} .8 \mathrm{~Hz}, 1 \mathrm{H}), 7.30(\mathrm{~s}, 1 \mathrm{H}) ;{ }^{13} \mathrm{C} \mathrm{NMR}\left(\mathrm{CDCl}_{3}\right) \delta$ 20.9, $\delta 44.1,56.0,56.1,72.3,78.8,120.8,126.5$, 129.1, 133.1, 133.2, 156.4; HRMS (ESI) $\mathrm{m} / z$ : calculated for $\mathrm{C}_{12} \mathrm{H}_{17} \mathrm{~N}_{2} \mathrm{O}[\mathrm{M}+\mathrm{H}]^{+}$205.1341, found 205.1335.

10-Methoxy-1,2,3,5,6,11b-hexahydroimidazo[1,2-d][1,4]benzoxazepine (17). The crude product was purified by washing with EtOAc to give pale yellow solid, yield $91 \% ; \mathrm{mp} 81-82{ }^{\circ} \mathrm{C} ;{ }^{1} \mathrm{H} \mathrm{NMR}\left(\mathrm{CDCl}_{3}\right) \delta 2.13(\mathrm{br}, 1 \mathrm{H}), 2.60$ (br, 1H), $2.92(\mathrm{br}, 1 \mathrm{H}), 3.18(\mathrm{~m}, 3 \mathrm{H}), 3.30(\mathrm{~m}, 1 \mathrm{H}), 3.75(\mathrm{~m}+\mathrm{s}, 4 \mathrm{H}), 4.25(\mathrm{~m}, 1 \mathrm{H}), 4.48,(\mathrm{~s}, 1 \mathrm{H}), 6.67(\mathrm{dd}, J 2.7 \mathrm{and}$ $8.7 \mathrm{~Hz}, 1 \mathrm{H}), 6.90(\mathrm{~d}, J 8.7 \mathrm{~Hz}, 1 \mathrm{H}), 7.11(\mathrm{~d}, J 2.7 \mathrm{~Hz}, 1 \mathrm{H}) ;{ }^{13} \mathrm{C} \mathrm{NMR}\left(\mathrm{CDCl}_{3}\right) \delta 44.1,55.7,56.2,56.4,72.4,78.6$, 111.3, 113.6, 121.8, 135.1, 152.4, 155.8; HRMS (ESI) $\mathrm{m} / \mathrm{z}$ : calculated for $\mathrm{C}_{12} \mathrm{H}_{17} \mathrm{~N}_{2} \mathrm{O}_{2}[\mathrm{M}+\mathrm{H}]^{+}$221.1290, found 221.1285.

General Procedure for the Preparation of [1,4]Benzoxazepines (20-26) and (27-33). In a $20 \mathrm{~mL}$ one-necked round-bottom flask equipped with a magnetic stirrer bar, saturated benzoxazepine 13-19 (1 mmol) was dissolved in DMF $(5 \mathrm{~mL})$. To this well-stirred solution at $\mathrm{rt}, \mathrm{KMnO}_{4}(2 \mathrm{mmol})$ was added gradually. The reaction mixture was left stirring at $\mathrm{rt}$ for $24 \mathrm{~h}$. The reaction mixture was diluted with $\mathrm{CHCl}_{3}(20 \mathrm{ml})$ and filtered. The filtrate was washed with $10 \mathrm{~mL}$ of saturated aq NaCl and then with $10 \mathrm{~mL}$ of $\mathrm{H}_{2} \mathrm{O}$. After drying and evaporating the solvent, the crude product was purified as indicated for individual reaction.

5,6-Dihydroimidazo[1,2- $d][1,4]$ benzoxazepine (20) and 2,3,5,6-tetrahydroimidazo[1,2- $d][1,4]$ benzoxazepine (27). The crude product was purified by preparative TLC using $\mathrm{CHCl}_{3}: \mathrm{CH}_{3} \mathrm{OH}(9: 1)+$ few drops of TEA to give: Compound (20). Light-brown solid (0.091 g, 48\%), mp 100-101 ${ }^{\circ} \mathrm{C}$ (lit mp 102-104 $\left.{ }^{\circ} \mathrm{C}\right)^{15} ;{ }^{1} \mathrm{H} \mathrm{NMR}\left(\mathrm{CDCl}_{3}\right) \delta 4.34$ $(\mathrm{m}, 2 \mathrm{H}), 4.41(\mathrm{~m}, 2 \mathrm{H}), 6.95(\mathrm{~s}, 1 \mathrm{H}), 7.97(\mathrm{~d}, J 8.1 \mathrm{~Hz}, 1 \mathrm{H}), 7.08(\mathrm{t}, J 7.3 \mathrm{~Hz}, 1 \mathrm{H}), 7.14(\mathrm{~s}, 1 \mathrm{H}), 7.21(\mathrm{t}, J 7.2 \mathrm{~Hz}$, $1 \mathrm{H}), 8.48(\mathrm{~d}, \mathrm{~J} 8.0 \mathrm{~Hz}, 1 \mathrm{H}) ;{ }^{13} \mathrm{C} \mathrm{NMR}\left(\mathrm{CDCl}_{3}\right) \delta 49.9,68.4,118.7,120.4,121.7,122.9,129.0,129.8,130.1,144.4$, 155.4; HRMS (ESI) $\mathrm{m} / \mathrm{z}$ : calculated for $\mathrm{C}_{11} \mathrm{H}_{11} \mathrm{~N}_{2} \mathrm{O}[\mathrm{M}+\mathrm{H}]^{+}$187.0871, found 187.0866.

Compound (27). Light-brown solid (0.049 g, 26\%); mp 65-66.5 ${ }^{\circ} \mathrm{C} ;{ }^{1} \mathrm{H} \mathrm{NMR}\left(\mathrm{CDCl}_{3}\right) \delta 3.92(\mathrm{~m}, 2 \mathrm{H}), 4.10(\mathrm{~m}$, 2H), 4.33, (m, 2H), $4.52(\mathrm{~m}, 2 \mathrm{H}), 7.03(\mathrm{~d}, J 7.9 \mathrm{~Hz}, 1 \mathrm{H}), 7.17(\mathrm{t}, J 9 \mathrm{~Hz}, 1 \mathrm{H}), 7.50(\mathrm{t}, J 9 \mathrm{~Hz}, 1 \mathrm{H}), 8.40(\mathrm{~d}, J 8.1 \mathrm{~Hz}$, $1 \mathrm{H}$ ); ${ }^{13} \mathrm{C}$ NMR (DMSO- $d_{6}$ ) $\delta 44.4,47.1,49.7,65.3,114.2,116.2,117.9,127.4,127.7,152.5,159.2$; HRMS (ESI) $\mathrm{m} / \mathrm{z}$ : calculated for $\mathrm{C}_{11} \mathrm{H}_{13} \mathrm{~N}_{2} \mathrm{O}[\mathrm{M}+\mathrm{H}]^{+} 189.1028$, found 189.1022 . 
10-Chloro-5,6-dihydroimidazo[1,2-d][1,4]benzoxazepine (21) and 10-chloro-2,3,5,6-tetrahydroimidazo[1,2d][1,4]benzoxazepine (28). The crude product was purified by preparative TLC using EtOAc: $\mathrm{CH}_{3} \mathrm{OH}(8: 2)+$ few drops of TEA to give:

Compound (21). Light-brown solid (0.097 g, 44\%); mp 131-133 ${ }^{\circ} \mathrm{C}$ (lit. mp 128-130 $\left.{ }^{\circ} \mathrm{C}\right)^{15} ;{ }^{1} \mathrm{H} \mathrm{NMR}(\mathrm{CDCl})_{3} \delta$ $4.48(\mathrm{~m}, 4 \mathrm{H}), 6.97(\mathrm{br}, 1 \mathrm{H}), 7.06(\mathrm{~s}, 1 \mathrm{H}), 7.23(\mathrm{br}, 1 \mathrm{H}), 7.32(\mathrm{~s}, 1 \mathrm{H}), 8.55(\mathrm{~s}, 1 \mathrm{H}) ;{ }^{13} \mathrm{C} \mathrm{NMR}\left(\mathrm{CDCl}_{3}\right) \delta 50.9,69.7$, 121.0, 122.6, 122.8, 129.4, 129.5, 129.7, 129.9, 143.9, 154.7; HRMS (ESI) $\mathrm{m} / \mathrm{z}$ : calculated for $\left.\mathrm{C}_{11} \mathrm{H}_{10} \mathrm{ClN} \mathrm{N}_{2} \mathrm{O}+\mathrm{M}\right]^{+} 221.0482$, found 221.0476 .

Compound (28). Light-brown solid (0.071 g, 32\%); mp 61-62 ${ }^{\circ} \mathrm{C} ;{ }^{1} \mathrm{H} \mathrm{NMR}\left(\mathrm{CDCl}_{3}\right) \delta 3.43(\mathrm{br}, 2 \mathrm{H}), 3.57(\mathrm{~m}, 2 \mathrm{H})$, 3.85, (m, 2H), $4.29(\mathrm{br}, 2 \mathrm{H}), 6.88(\mathrm{~d}, J 8.7 \mathrm{~Hz}, 1 \mathrm{H}), 7.24(\mathrm{br}, 1 \mathrm{H}), 8.14(\mathrm{~s}, 1 \mathrm{H}) ;{ }^{13} \mathrm{C} \mathrm{NMR}\left(\mathrm{CDCl}_{3}\right) \delta$ 49.1, 51.9, 54.6, 70.2, 120.1, 122.4, 127.8, 131.5, 132.2, 155.9, 162.7; HRMS (ESI) $\mathrm{m} / \mathrm{z}$ : calculated for $\mathrm{C}_{11} \mathrm{H}_{12} \mathrm{ClN} \mathrm{N}_{2} \mathrm{O}[\mathrm{M}+\mathrm{H}]^{+} 223.0638$, found 223.0633 .

10-Bromo-5,6-dihydroimidazo[1,2-d][1,4]benzoxazepine (22) and 10-bromo-2,3,5,6-tetrahydroimidazo[1,2d][1,4]benzoxazepine (29). The crude product was purified by preparative TLC using $\mathrm{CHCl}_{3}: \mathrm{CH}_{3} \mathrm{OH}(9.5: 0.5)+$ few drops of TEA to give:

Compound (22). Colorless solid (0.101 g, 39\%); mp 118-120 ${ }^{\circ} \mathrm{C}$ (lit. mp 120-122 $\left.{ }^{\circ} \mathrm{C}\right)^{15} ;{ }^{1} \mathrm{H} \mathrm{NMR}\left(\mathrm{CDCl}_{3}\right) \delta 4.37$ $(\mathrm{m}, 2 \mathrm{H}), 4.42(\mathrm{~m}, 2 \mathrm{H}), 6.87(\mathrm{~d}, J 8.6 \mathrm{~Hz}, 1 \mathrm{H}), 6.97(\mathrm{br}, 1 \mathrm{H}), 7.16(\mathrm{~s}, 1 \mathrm{H}), 7.28(\mathrm{~m}, 1 \mathrm{H}), 8.65(\mathrm{~d}, J 2.1 \mathrm{~Hz}, 1 \mathrm{H}) ;{ }^{13} \mathrm{C}$ NMR $\left(\mathrm{CDCl}_{3}\right) \delta 49.9,68.4,115.6,122.2,122.3,128.9,132.2,132.6,143.3,154.4 ; \mathrm{HRMS}$ (ESI) $\mathrm{m} / \mathrm{z}$ : calculated for $\left.\mathrm{C}_{11} \mathrm{H}_{10} \mathrm{BrN} \mathrm{O}_{2} \mathrm{OM}+\mathrm{H}\right]^{+}$264.9976, found 264.9971 .

Compound (29). Colorless solid (0.100 g, 39\%); mp 71-72 ${ }^{\circ} \mathrm{C} ;{ }^{1} \mathrm{H}$ NMR $\left(\mathrm{CDCl}_{3}\right) \delta 3.41(\mathrm{~m}, 2 \mathrm{H}), 3.54(\mathrm{~m}, 2 \mathrm{H}), 3.82$ $(\mathrm{m}, 2 \mathrm{H}), 4.27(\mathrm{~m}, 2 \mathrm{H}), 6.80(\mathrm{br}, 1 \mathrm{H}), 7.34(\mathrm{~m}, 1 \mathrm{H}),, 8.28(\mathrm{~s}, 1 \mathrm{H}) ;{ }^{13} \mathrm{CNMR}\left(\mathrm{CDCl}_{3}\right) \delta 49.1,51.9,54.6,70.2,115.0$, 120.6, 122.8, 134.5, 135.0, 156.4, 162.5; HRMS (ESI) $m / z$ : calculated for $\mathrm{C}_{11} \mathrm{H}_{12} \mathrm{BrN}_{2} \mathrm{O}[\mathrm{M}+\mathrm{H}]^{+} 267.0133$, found 267.0128.

10-Methyl-5,6-dihydroimidazo[1,2-d][1,4]benzoxazepine (23) and 10-methyl-2,3,5,6-tetrahydroimidazo[1,2d][1,4]benzoxazepine (30). The crude product was purified by preparative TLC using EtOAc: $\mathrm{CH}_{3} \mathrm{OH}(7: 3)+$ few drops of TEA to give:

Compound (23). Beige solid (0.113 g, 56\%); mp 88-89 ${ }^{\circ} \mathrm{C}$ (lit. mp 91-93 $\left.{ }^{\circ} \mathrm{C}\right)^{15} ;{ }^{1} \mathrm{H} \mathrm{NMR}\left(\mathrm{CDCl}_{3}\right) \delta 2.32(\mathrm{~s}, 3 \mathrm{H})$, 4.35-4.41 (m, 4H), $6.88(\mathrm{~d}, J 8.3 \mathrm{~Hz}, 1 \mathrm{H}), 6.95(\mathrm{~s}, 1 \mathrm{H}), 7.02(\mathrm{~d}, J 7.6 \mathrm{~Hz}, 1 \mathrm{H}), 7.15(\mathrm{~s}, 1 \mathrm{H}), 8.29(\mathrm{~s}, 1 \mathrm{H}) ;{ }^{13} \mathrm{C} \mathrm{NMR}$ $\left(\mathrm{CDCl}_{3}\right) \delta 20.5,50.0,68.4,120.2,121.6,128.9,129.9,130.7,132.4,153.4$; HRMS (ESI) $\mathrm{m} / \mathrm{z}$ : calculated for $\mathrm{C}_{12} \mathrm{H}_{13} \mathrm{~N}_{2} \mathrm{O}[\mathrm{M}+\mathrm{H}]^{+}$201.1028, found 201.1022.

Compound (30). Colorless solid (0.065 g, 32\%); mp 60-61 ${ }^{\circ} \mathrm{C} ;{ }^{1} \mathrm{H}$ NMR $\left(\mathrm{CDCl}_{3}\right) \delta 2.31(\mathrm{~s}, 3 \mathrm{H}), 3.80(\mathrm{br}, 2 \mathrm{H}), 4.10$ $(\mathrm{m}, 2 \mathrm{H}), 4.20(\mathrm{~m}, 2 \mathrm{H}), 4.45(\mathrm{br}, 2 \mathrm{H}), 6.86(\mathrm{~d}, J 8.4 \mathrm{~Hz}, 1 \mathrm{H}), 7.25(\mathrm{~d}, J 8.5 \mathrm{~Hz}, 1 \mathrm{H}), 8.38(\mathrm{~s}, 1 \mathrm{H}) ;{ }^{13} \mathrm{C} \mathrm{NMR}\left(\mathrm{CDCl}_{3}\right) \delta$ 20.2 , 43.1, 50.2, 53.4, 69.1, 109.8, 121.2, 132.6, 133.7, 137.5, 157.5, 162.7; HRMS (ESI) $\mathrm{m} / \mathrm{z}$ : calculated for $\mathrm{C}_{12} \mathrm{H}_{15} \mathrm{~N}_{2} \mathrm{O}[\mathrm{M}+\mathrm{H}]^{+}$203.1184, found 203.1179.

10-Methoxy-5,6-dihydroimidazo[1,2-d][1,4]benzoxazepine (24) and 10-methoxy-2,3,5,6-tetrahydroimidazo $[1,2-d][1,4]$ benzoxazepine (31). The crude product was purified by preparative TLC using EtOAc: $\mathrm{CH}_{3} \mathrm{OH}(8: 2)+$ few drops of TEA to give:

Compound (24). Pale brown solid (0.117 g, 54\%); mp 83-84.5 ${ }^{\circ} \mathrm{C}$ (lit. mp 86-88 $\left.{ }^{\circ} \mathrm{C}\right)^{15} ;{ }^{1} \mathrm{H} \mathrm{NMR}(\mathrm{CDCl})_{3} \delta 3.83(\mathrm{~s}$, $3 \mathrm{H}), 4.35-4.38(\mathrm{~m}, 4 \mathrm{H}), 6.78(\mathrm{~m}, 1 \mathrm{H}), 6.90(\mathrm{~d}, J \quad 8.8 \mathrm{~Hz}, 1 \mathrm{H}), 7.00(\mathrm{~s}, 1 \mathrm{H}), 7.15(\mathrm{~s}, 1 \mathrm{H}), 7.92(\mathrm{~d}, J 2.7 \mathrm{~Hz}, 1 \mathrm{H}) ;{ }^{13} \mathrm{C}$ NMR $\left(\mathrm{CDCl}_{3}\right) \delta 50.1,55.8,68.5,111.7,117.8,119.4,121.6,121.9,129.1,144.4,149.7,155.1$; HRMS (ESI) $\mathrm{m} / \mathrm{z}$ : calculated for $\mathrm{C}_{12} \mathrm{H}_{13} \mathrm{~N}_{2} \mathrm{O}_{2}[\mathrm{M}+\mathrm{H}]^{+} 217.0977$, found 217.0972 .

Compound (31). Pale yellow solid $(0.055 \mathrm{~g}, 25 \%)$; $\mathrm{mp} \mathrm{69-70}{ }^{\circ} \mathrm{C} ;{ }^{1} \mathrm{H}$ NMR $\left(\mathrm{CDCl}_{3}\right) \delta 3.59(\mathrm{~m}, 2 \mathrm{H}), 3.88(\mathrm{~s}+\mathrm{m}, 5 \mathrm{H})$, $3.99(\mathrm{~m}, 2 \mathrm{H}), 4.31(\mathrm{~m}, 2 \mathrm{H}), 6.90(\mathrm{~d}, J 8.8 \mathrm{~Hz}, 1 \mathrm{H}), 6.97(\mathrm{~d}, J 8.9 \mathrm{~Hz}, 1 \mathrm{H}), 7.72(\mathrm{~s}, 1 \mathrm{H}) ;{ }^{13} \mathrm{C} \mathrm{NMR}\left(\mathrm{CDCl}_{3}\right) \delta 49.5$, $53.9,56.5,56.7,69.7,113.5,122.5,122.6,163.4$; HRMS (ESI) $m / z$ : calculated for $\mathrm{C}_{12} \mathrm{H}_{15} \mathrm{~N}_{2} \mathrm{O}_{2}[\mathrm{M}+\mathrm{H}]^{+} 219.1134$, found 219.1128 . 
10-Nitro-5,6-dihydroimidazo[1,2-d][1,4]benzoxazepine (25) and 10-nitro-2,3,5,6-tetrahydroimidazo[1,2- $d$ ] $[1,4]$ benzoxazepine (32). The crude product was purified by preparative TLC using $\mathrm{CHCl}_{3}: \mathrm{CH}_{3} \mathrm{OH}(9.5: 0.5)+$ few drops of TEA to give:

Compound (25). Pale yellow solid (0.088 g, 38\%); $\mathrm{mp}>200^{\circ} \mathrm{C}$ (decomp.); ${ }^{1} \mathrm{H} N M R\left(\mathrm{CDCl}_{3}\right) \delta 4.42(\mathrm{~m}, 2 \mathrm{H}), 4.53$ $(\mathrm{m}, 2 \mathrm{H}), 6.99-7.07(\mathrm{br}, 2 \mathrm{H}), 7.17(\mathrm{br}, 1 \mathrm{H}), 8.02(\mathrm{~d}, J 8.3 \mathrm{~Hz}, 1 \mathrm{H}), 9.40(\mathrm{~s}, 1 \mathrm{H}) ;{ }^{13} \mathrm{C} \mathrm{NMR}\left(\mathrm{CDCl}_{3}\right) \delta 49.5,68.9$, 119.1, 121.6, 122.5, 124.2, 126.5, 129.9, 159.2, 163.8; HRMS (ESI) $\mathrm{m} / \mathrm{z}$ : calculated for $\mathrm{C}_{11} \mathrm{H}_{10} \mathrm{~N}_{3} \mathrm{O}_{3}[\mathrm{M}+\mathrm{H}]^{+}$232.0722, found 232.0717.

Compound (32). Yellow solid (0.121 g, 52\%); mp 148-150 ${ }^{\circ} \mathrm{C} ;{ }^{1} \mathrm{H}$ NMR $\left(\mathrm{CDCl}_{3}\right) \delta$ 3.50-3.57 (br 4H), $3.87(\mathrm{br}, 2 \mathrm{H})$, 4.40 (br, 2H), 7.01 (br, 1H), $8.10(\mathrm{br}, 1 \mathrm{H}), 9.10(\mathrm{br}, 1 \mathrm{H}) ;{ }^{13} \mathrm{C} \mathrm{NMR}\left(\mathrm{CDCl}_{3}\right) \delta 48.9,52.7,55.0,70.5,121.8,126.6$, 129.3, 142.6, 161.6; HRMS (ESI) $m / z$ : calculated for $\mathrm{C}_{11} \mathrm{H}_{12} \mathrm{~N}_{3} \mathrm{O}_{3}[\mathrm{M}+\mathrm{H}]^{+} 234.0879$, found 234.0873.

5,6-Dihydroimidazo[1,2-d]naphtho[2,3-f][1,4]oxazepine (26) and 2,3,5,6-tetrahydroimidazo [1,2-d]naphtho $[2,3-f][1,4]$ oxazepine (33). The crude product was purified by preparative TLC using $\mathrm{CHCl}_{3}: \mathrm{CH}_{3} \mathrm{OH}(9.5: 0.5)+$ few drops of TEA to give:

Compound (26). Pink solid (0.114 g, 48\%); mp 155-156 ${ }^{\circ} \mathrm{C} ;{ }^{1} \mathrm{H}$ NMR (CDCl 3$) \delta 4.41$ (br, $2 \mathrm{H}$ ), $4.49(\mathrm{br}, 2 \mathrm{H}), 7.01$ $(\mathrm{s}, 1 \mathrm{H}), 7.22(\mathrm{~s}, 1 \mathrm{H}), 7.32-7.42(\mathrm{~m}, 3 \mathrm{H}), 7.66(\mathrm{~d}, J 8.1 \mathrm{~Hz}, 1 \mathrm{H}), 7.86(\mathrm{~d}, J 8.1 \mathrm{~Hz}, 1 \mathrm{H}), 9.02(\mathrm{br}, 1 \mathrm{H}) ;{ }^{13} \mathrm{C} \mathrm{NMR}$ $\left(\mathrm{CDCl}_{3}\right) \delta$ 50.0, 69.0, 116.2, 120.6, 121.9, 125.0, 126.4, 127.2, 128.6, 129.1, 130.0, 130.2, 134.1, 144.8, 153.4; HRMS (ESI) $m / z$ : calculated for $\mathrm{C}_{15} \mathrm{H}_{13} \mathrm{~N}_{2} \mathrm{O}[\mathrm{M}+\mathrm{H}]^{+} 237.1028$, found 237.1022 .

Compound (33). Brown solid (0.091 g, 38\%); mp 99-101 ${ }^{\circ} \mathrm{C} ;{ }^{1} \mathrm{H}$ NMR $\left(\mathrm{CDCl}_{3}\right) \delta 3.54$ (t, J $\left.4.9 \mathrm{~Hz}, 2 \mathrm{H}\right), 3.79(\mathrm{t}, J$ $9.9 \mathrm{~Hz}, 2 \mathrm{H}), 4.00(\mathrm{t}, J 10 \mathrm{~Hz}, 2 \mathrm{H}), 4.37(\mathrm{t}, J 4.9 \mathrm{~Hz}, 2 \mathrm{H}), 7.22(\mathrm{~s}, 1 \mathrm{H}), 7.38(\mathrm{t}, J 7 \mathrm{~Hz}, 1 \mathrm{H}), 7.48(\mathrm{t}, J 7 \mathrm{~Hz}, 1 \mathrm{H})$, $7.66(\mathrm{~d}, J 8.3 \mathrm{~Hz}, 1 \mathrm{H}), 7.92(\mathrm{~d}, J 8.1 \mathrm{~Hz}, 1 \mathrm{H}), 9.00(\mathrm{~s}, 1 \mathrm{H}) ;{ }^{13} \mathrm{C} \mathrm{NMR}\left(\mathrm{CDCl}_{3}\right) \delta$ 48.8, 53.9, 70.4, 117.4, 125.5, 126.4, 128.7, 129.4, 129.8, 133.9, 153.8, 164.2; HRMS (ESI) $\mathrm{m} / \mathrm{z}$ : calculated for $\mathrm{C}_{15} \mathrm{H}_{15} \mathrm{~N}_{2} \mathrm{O}[\mathrm{M}+\mathrm{H}]^{+} 239.1184$, found 239.1179 .

General Procedure for the Preparation of [1,4]Benzoxazepines (35-39). In a $50 \mathrm{~mL}$ two-necked round bottom flask equipped with a magnetic stirrer bar, a reflux condenser, 2-(2-bromoethoxy)benzaldehyde (2 $\mathrm{mmol})$ and ortho-phenylenediamine $(2 \mathrm{mmol})$ were dissolved in anhydrous MeCN $(25 \mathrm{ml})$. To this well-stirred solution at rt was added $\mathrm{Na}_{2} \mathrm{~S}_{2} \mathrm{O}_{5}(4 \mathrm{mmol})$ gradually. The reaction mixture was refluxed with stirring for 24-48 $\mathrm{h}$. The reaction mixture was filtered after cooling, and the solvent was evaporated. The crude product was purified by flash chromatography using EtOAc:hexane (3:7).

6,7-Dihydrobenzo[f]-4,5-imidazo[1,2-d][1,4]oxazepine (35). Beige solid(0.320 g, 58\%); sample was crystallized from ethanol mp 211-213 ${ }^{\circ} \mathrm{C}$ (lit. mp 208-209 ${ }^{\circ} \mathrm{C}$ ) ${ }^{10} ;{ }^{1} \mathrm{H} \mathrm{NMR}\left(\mathrm{CDCl}_{3}\right) \delta 4.52(\mathrm{~m}, 2 \mathrm{H}), 4.61(\mathrm{~m}, 2 \mathrm{H}), 7.10(\mathrm{dd}, \mathrm{J}$ 1.5 and $8.5 \mathrm{~Hz}, 1 \mathrm{H}), 7.19-7.23(\mathrm{~m}, 1 \mathrm{H}), 7.28-7.41(\mathrm{~m}, 4 \mathrm{H}), 7.86(\mathrm{~m}, 1 \mathrm{H}), 8.78(\mathrm{dd}, J 2.0$ and $8.0 \mathrm{~Hz}, 1 \mathrm{H}) ;{ }^{13} \mathrm{C} \mathrm{NMR}$ $\left(\mathrm{CDCl}_{3}\right) \delta$ 47.1, 68.9, 109.2, 118.4, 119.6, 120.8, 122.9, 123.0, 123.1, 131.5, 131.7, 136.2, 142.4, 150.1, 157.1; HRMS (ESI) $m / z$ : calculated for $\mathrm{C}_{15} \mathrm{H}_{13} \mathrm{~N}_{2} \mathrm{O}[\mathrm{M}+\mathrm{H}]^{+} 237.1028$, found 237.1022.

2-Bromo-6,7-dihydrobenzo[f]-4,5-imidazo[1,2-d][1,4]oxazepine (36). Beige solid (0.361 g, 58\%); sample was crystallized from methanol mp 217-219 ${ }^{\circ} \mathrm{C} ;{ }^{1} \mathrm{H} \mathrm{NMR}\left(\mathrm{CDCl}_{3}\right) \delta 4.52(\mathrm{~m}, 2 \mathrm{H}), 4.59(\mathrm{~m}, 2 \mathrm{H}), 6.97(\mathrm{~d}, J 11 \mathrm{~Hz}, 1 \mathrm{H})$, 7.32-7.37 (m, 3H), $7.42(\mathrm{dd}, J 3.0$ and $7.5 \mathrm{~Hz}, 1 \mathrm{H}), 7.84(\mathrm{~m}, 1 \mathrm{H}), 8.92(\mathrm{~d}, J 3.0 \mathrm{~Hz}, 1 \mathrm{H}) ;{ }^{13} \mathrm{C} \mathrm{NMR}\left(\mathrm{CDCl}_{3}\right) \delta 47.1$, 69.0, 109.2, 115.7, 119.8, 120.2, 122.6, 123.2, 123.3, 133.7, 134.1, 136.3, 142.3, 148.6, 156.1; HRMS (ESI) $\mathrm{m} / z$ : calculated for $\mathrm{C}_{15} \mathrm{H}_{12} \mathrm{BrN}_{2} \mathrm{O}[\mathrm{M}+\mathrm{H}]^{+} 315.0133$, found 315.0128

2-Nitro-6,7-dihydrobenzo[f]-4,5-imidazo[1,2-d][1,4]oxazepine (37). Pale brown solid (0.370 g, 66\%); sample was washed with methanol and then with ethylacetate mp 224-226 ${ }^{\circ} \mathrm{C} ;{ }^{1} \mathrm{H} N M R\left(\mathrm{CDCl}_{3}\right) \delta 4.61(\mathrm{~m}, 2 \mathrm{H}), 4.73$ $(\mathrm{m}, 2 \mathrm{H}), 7.19(\mathrm{~d}, J 11 \mathrm{~Hz}, 1 \mathrm{H}), 7.36(\mathrm{~m}, 3 \mathrm{H}), 7.88(\mathrm{~m}, 3 \mathrm{H}), 8.17(\mathrm{dd}, J 3.0$ and $11.5 \mathrm{~Hz}, 1 \mathrm{H}), 9.71(\mathrm{~d}, J 1.5 \mathrm{~Hz}$, $1 \mathrm{H}) ;{ }^{13} \mathrm{C} \mathrm{NMR}\left(\mathrm{CDCl}_{3}\right) \delta 46.7,69.4,109.2,118.7,120.2,121.9,123.4,123.7,125.7,128.1,136.3,142.5,143.2$, 147.7, 160.8; HRMS (ESI) $m / z$ : calculated for $\mathrm{C}_{15} \mathrm{H}_{12} \mathrm{~N}_{3} \mathrm{O}_{3}[\mathrm{M}+\mathrm{H}]^{+} 282.0879$, found 282.0873 
6,7-Dihydrobenzo[4,5]imidazo[1,2-d]naphtho[2,3-f][1,4]oxazepine (38). Pale brown solid (0.270 g, 47\%); sample was washed with EtOAc mp 196-198 ${ }^{\circ} \mathrm{C} ;{ }^{1} \mathrm{H}$ NMR $\left(\mathrm{CDCl}_{3}\right) \delta 4.57(\mathrm{~m}, 2 \mathrm{H}), 4.69(\mathrm{~m}, 2 \mathrm{H}), 7.29(\mathrm{~s}, 1 \mathrm{H}), 7.35-$ $7.57(\mathrm{~m}, 4 \mathrm{H}), 7.54(\mathrm{~s}, 1 \mathrm{H}), 7.76(\mathrm{~d}, J 10.5 \mathrm{~Hz}, 1 \mathrm{H}), 7.91-7.93(\mathrm{~m}, 1 \mathrm{H}), 8.00(\mathrm{~d}, J 10.5 \mathrm{~Hz}, 1 \mathrm{H}), 9.33(\mathrm{~s}, 1 \mathrm{H}) ;{ }^{13} \mathrm{C}$ $\operatorname{NMR}\left(\mathrm{CDCl}_{3}\right) \delta 47.2,69.4,109.4,116.7,119.6,120.5,123.1,123.2,125.3,126.5,127.9,128.9,130.0,132.5$, 135.0, 136.2, 142.4, 150.0, 154.4; HRMS (ESI) $\mathrm{m} / \mathrm{z}$ : calculated for $\mathrm{C}_{19} \mathrm{H}_{15} \mathrm{~N}_{2} \mathrm{O}[\mathrm{M}+\mathrm{H}]^{+}$287.1184, found 287.1179

8,9-Dihydrobenzo[4,5]imidazo[1,2-d]naphtho[1,2-f][1,4]oxazepine (39). Yellow solid (0.392 g, 51\%); sample was washed with EtOAc mp $129-131{ }^{\circ} \mathrm{C} ;{ }^{1} \mathrm{H} \mathrm{NMR}\left(\mathrm{CDCl}_{3}\right) \delta 4.29(\mathrm{t}, J 7.5 \mathrm{~Hz}, 2 \mathrm{H}), 4.61(\mathrm{t}, J 7.5 \mathrm{~Hz}, 2 \mathrm{H}), 7.18(\mathrm{~s}$, $1 \mathrm{H})$, 7.27-7.31 (m, 2H), $7.37(\mathrm{~m}, 1 \mathrm{H}), 7.42(\mathrm{~m}, 1 \mathrm{H}), 7.51(\mathrm{~m}, 1 \mathrm{H}), 7.80(\mathrm{~d}, J 10.0 \mathrm{~Hz}, 1 \mathrm{H}), 7.88(\mathrm{~s}, 1 \mathrm{H}), 7.90(\mathrm{~m}$, $1 \mathrm{H}), 8.86(\mathrm{~s}, 1 \mathrm{H}) ;{ }^{13} \mathrm{C} \mathrm{NMR}\left(\mathrm{CDCl}_{3}\right) \delta$ 41.2, 74.4, 108.6, 118.6, 120.3, 121.9, 122.4, 122.9, 125.6, 126.2, 127.9, $128.1,131.3,132.2,132.5,134.0,143.4,150.3,153.1 ;$ HRMS (ESI) $\mathrm{m} / \mathrm{z}$ : calculated for $\mathrm{C}_{19} \mathrm{H}_{15} \mathrm{~N}_{2} \mathrm{O}[\mathrm{M}+\mathrm{H}]^{+} 287.1184$, found 287.1179

\section{Crystal structure determination}

The crystal structures of compounds 16, 29 and 36 were determined at $r$ using an 'Xcalibur, Eos' diffractometer (Mo K $\alpha$ radiation, $\lambda=0.7107 \AA$ ). Data were acquired and processed to give $h k l$ files using CrysAlisPro software. ${ }^{26}$ A preliminary solution of the structures was obtained using the Olex2 program, then, the structure solutions were refined and finalized using the SHELXTL program package. ${ }^{27}$ Atoms other than hydrogen were refined anisotropically. Hydrogen atoms were placed in the calculated positions using a riding model. Summary of data collection parameters and refinement results are given in Supplementary Material. The CIF files of compounds 16, 29 and $\mathbf{3 6}$ were deposited in Cambridge Crystallographic Data Center. Their CCDC are 1897620, 1897621 and 1897622, repectively.

\section{Acknowledgements}

Many thanks to the Chemistry Department at The University of Jordan for running the NMR, HRMS spectra and X-ray structure analysis.

\section{Supplementary Material}

Copies of ${ }^{1} \mathrm{H},{ }^{13} \mathrm{C}$ NMR and of HRMS spectra for compounds 14-17, 20-33 and 35-39 and a table of crystal data for structures 16, 29, 36 can be found in the Supplementary Material.

\section{References}

1. Grunewald, G. L.; Dahanukar, V. H.; Ching, P.; Criscione, K. R. J. Med Chem. 1996, 39, 3539. https://doi.org/10.1021/jm9508292

2. Kapur, S.; Cho, R.; Jones, C.; McKay, G.; Zipursky, R. B. Biol. Psych. 1999, 45, 1217. https://doi.org/10.1016/S0006-3223(98)00204-2 
3. Umemiya, H.; Fukasawa, H.; Ebisawa, M.; Eyrolles, L.; Kawachi, E.; Eisenmann, G.; Gronemeyer, H.; Hashimoto, Y.; Shudo, K.; Kagechika, H. J. Med. Chem. 1997, 40, 4222.

https://doi.org/10.1021/jm9704309

4. Klunder, J. M.; Hargrave, K. D.; West, M.; Cullen, E.; Pal, K.; Behnke, M. L.; Kapadia, S. R.; McNeil, D. W.; Wu, J. C.; Chow, G. C. J. Med. Chem. 1992, 35, 1887.

https://doi.org/10.1021/jm00088a027

5. Fu, P.; Jamison, M.; La, S.; MacMillan, J. B. Org. Lett. 2014, 16, 5656. https://doi.org/10.1021/ol502731p

6. Yoo, C. B.; Jones, P. A. Nat. Rev. Drug Discovery 2006, 5, 37. https://doi.org/10.1038/nrd1930

7. Ndubaku, C. O.; Heffron, T. P.; Staben, S. T; Baumgardner, M.; Blaquiere, N.; Bradley, E.; Bull, R.; Do, S.; Dotson, J.; Dudley, D.; Edgar, K. A.; Friedman, L. S.; Goldsmith, R.; Heald, R. A.; Kolesnikov, A.; Lee, L.; Lewis, C.; Nannini, M.; Nonomiya, J.; Pang, J.; Price, S.; Prior, W. W.; Salphati, L.; Sideris, S.; Wallin, J. J.; Wang, L.; Wei, B.; Sampath, D.; Olivero, A. G. J. Med. Chem. 2013, 56, 4597.

8. Safina, B. S.; Elliott, R. L.; Forrest, A. K.; Heald, R. A.; Murray, J. M.; Nonomiya, J.; Pang, J.; Salphati, L.; Seward, E. M.; Staben, S. T.; Ultsch, M.; Wei, B.; Yang, W; Sutherlin, D. P. Med. Chem. Lett. 2017, 8, 936. https://doi.org/10.1021/acsmedchemlett.7b00170

9. Castanedo, G. M.; Blaquiere, N.; Beresini, M.; Bravo, B.; Brightbill, H.; Chen, J.; Cui, H.; Eigenbrot, C.; Everett, C.; Feng, J.; Godemann, R.; Gogol, E.; Hymowitz, S.; Johnson, A.; Kayagaki, N.; Kohli, P. B.; Knüppel, K.; Kraemer, J.; Krüger, S.; Loke, P.; McEwan, P.; Montalbetti, C.; Roberts, D. A.; Smith, M; Steinbacher, S.; Bhaskar, S. S.; Takahashi, R.; Wang, X.; Wu, L. C.; Zhang, Y.; Staben, S. T. J. Med. Chem. 2017, 60, 627.

https://doi.org/10.1021/acs.jmedchem.6b01363

10. Yin, Y.; Zhang,Y. Q.; Jin, B.; Sha, S.; Wu, X.; Sangani, C. B.; Wang, S. F.; Qiao, F.; Lu, A. M.; Lv, P. C.; Zhu, H. L. Bioorg. Med. Chem. 2015, 23, 1231.

11. Staben, S. T.; Siu, M.; Goldsmith, R.; Olivero, A. G.; Do, S.; Burdick, D. J.; Heffron, T. P.; Dotson, J.; Sutherlin, D. P.; Zhu, B. Y.; Tsui, V.; Le, H.; Lee, L.; Lesnick, J.; Lewis, C; Murray, J. M.; Nonomiya, J.; Pang, J.; Prior, W. W.; Salphati, L.; Rouge, L.; Sampath, D.; Sideris, S.; Wiesmann, C; Wu, P. Bioorg. Med. Lett. 2011, 21, 4054. https://doi.org/10.1016/i.bmcl.2011.04.124

12. Rewcastle, G. W.; Gamage, S. A.; Flanagan, J. U.; Frederick, R.; Denny, W. A.; Baguley, B. C.; Kestell, P; Singh, R.; Kendall, J. D.; Marshall, E. S.; Lill, C. L.; Lee, W. J.; Kolekar, S.; Buchanan, C. M.; Jamieson, S. M. F.; Shepherd, P. R. J. Med. Chem. 2011, 54, 7105.

13. Heffron, T. P.; Wei, B. Q.; Olivero, A.; Staben, S. T.; Tsui, V.; Do, S.; Dotson, J.; Folkes, A. J.; Goldsmith, P.; Goldsmith, R.; Gunzner, J.; Lesnick, J.; Lewis, C; Mathieu, S.; Nonomiya, J.; Shuttleworth, S.; Sutherlin, D. P.; Wan, N. C.; Wang, S.; Wiesmann, C.; Zhu, B. Y. J. Med. Chem. 2011, 54, 7815. https://doi.org/10.1021/jm2007084

14. Staben, S. T.; Ndubaku, C.; Blaquiere, N. Bioorg. Med. Lett. 2013, 23, 2606.

15. Dalziel, M.E.; Deichert, J. A.; Carrera, D. E.; Beaudry, D.; Han, C.; Zhang, H.; Angelaud, R. Org. Lett. 2018, 4, 2624.

https://doi.org/10.1021/acs.orglett.8b00824

16. Hezarkhani, Z.; Faroghi, M. T.; Shaabani, A. Appl. Organomet. Chem. 2017, e3764. https://doi.org/10.1002/aoc.3764

17. Yavari, H.; Alinezhad, H.; Shafieeb, A. J. Heterocycl. Chem. 2017, 54, 2393. 
18. Yavari, H.; Alinezhad, H.; Tajbakhsh, M. Res. Chem. Intermed. 2017, 43, 3283. https://doi.org/10.1007/s11164-016-2825-z

19. Srinivasulu, V.; Shehadeh, I; Khanfar, M. A.; Malik, O. G.; Tarazi, H.; Abu-Yousef, I. A.; Sebastian, A.; Baniowda, N.; O'Connor, M. J.; Al-Tel, T. H. J. Org. Chem. 2019, 84, 934.

https://doi.org/10.1021/acs.joc.8b02878

20. Levan, K. R.; Root, C. A. Inorg. Chem. 1981, 20, 3566. https://doi.org/10.1364/AO.20.003566

21. Levan, K. R.; Root, C. A. J. Org. Chem. 1981, 46, 2404.

22. Mizyed, S. A.; Ashram M.; Awwadi, F. F. Arkivoc 2011,(x), 277. https://doi.org/10.3998/ark.5550190.0012.a22

23. Ashram M.; Awwadi, F. F. Arkivoc 2019, (v), 142. https://doi.org/10.24820/ark.5550190.p010.780

24. Navarrete-Vázquez, G.; Moreno-Diaz, H.; Aguirre-Crespo, F.; León-Rivera, I.; Villalobos-Molina, R.; MuñozMuñiz, O.; Estrada-Soto, S. Bioorg. Med. Chem. Lett. 2006, 16, 4169. https://doi.org/10.1016/j.bmcl.2006.05.082

25. Awwadi, F. F.; Willett, R. D.; Peterson, K. A.; Twamley, B. J. Phys. Chem. A, 2007, 111, 2319. https://doi.org/10.1021/jp0660684

26. CrysAlisPro, Oxford Diffraction Ltd., Version 1.171.35.19 (release 27-10-2011 CrysAlis171.NET).

27. SHELXTL (XPREP, X., XL, XP, XCIF), version 6.10; Bruker AXS Inc.: Madison, WI., 2002. 